\title{
Activity Budgets and Forage Selection of Podolian Cattle, a Semiwild Bovine Breed
}

\author{
Fabio Napolitano, Antonio Girolami, Corrado Pacelli, and Ada Braghieri \\ Dipartimento di Scienze delle Produzioni Animali, Università degli Studi della Basilicata, Via dell'Ateneo Lucano 10, \\ 85100 Potenza, Italy \\ Correspondence should be addressed to Ada Braghieri, ada.braghieri@unibas.it
}

Received 23 February 2011; Accepted 19 March 2011

Academic Editors: B. I. Crother and K. E. Ruckstuhl

Copyright ( $\odot 2011$ Fabio Napolitano et al. This is an open access article distributed under the Creative Commons Attribution License, which permits unrestricted use, distribution, and reproduction in any medium, provided the original work is properly cited.

This study aimed to describe the behaviour of Podolian breed, a semiwild cattle breed kept in a natural environment (as either a small group of young bulls or cows within a family herd), and the interaction of these animals with the environment in terms of ingestion from natural pastures. Diurnal grazing behavioural pattern was monitored through continuous focal animal recording method. The activity budget of free-ranging animals was characterized by high locomotor and feeding activities. They exhibited a high degree of adaptability to the local phytocoenosis with high levels of ferns' and tree foliage intakes performed by cows and the selection of a diet more nutritious than pasture performed by young bulls. These results along with the low levels of agonistic interactions recorded in the two experiments suggest that extensive systems based on grazing allow social stability and provide a natural environment for the expression of cattle species-specific behaviour.

\section{Introduction}

The Podolian breed is a native breed traditionally kept on pastures in Southern Italy. It has been subjected to a lower selective pressure (artificial insemination has been rarely used) and a higher natural selection (animals kept in natural environments, where food search, avoidance of predators, maternal care, etc. were essential) as compared to other breeds, so that it can be still considered a semiwild population [1].

Natural pastures provide an environment where animals can express their own natural behaviour. Apart from wild ancestors, which for cattle are extinct, and few examples of feral populations (e.g., [2]), domestic herds kept in natural environments represent the main source of information about natural behaviour. In addition, pasture-based farming can eliminate the concentration of manure, reduce the competition with humans in terms of food, increase animal welfare, and be perceived by citizens as ethically sound $[1,3]$.

However, herbage production from natural pastures located in less favoured areas, where Podolian cattle are usually kept, is characterized by being unevenly distributed throughout the year. These areas are also characterized by being upland and with soils of low fertility. Therefore, the fitness of grazing animals depends on their ability to ingest a diet adequate to meet their nutrient requirements for maintenance, growth, and reproduction. This in turn is regulated by a series of short-term decisions made by the animal about which plants to select and how long to search between bites. Long term decisions concern the length of time to spend feeding and where to feed, given topographic influences on energy expenditure and distance travelled between foraging sites, water, and shelter. This suite of decision-making processes is defined as the "foraging strategy of the animal" [4].

The availability and quality of forage for grazing ruminants in the Mediterranean areas changes spatially and seasonally [5]. Crude protein concentrations decline and fibre levels increase as herbaceous plants tend to become senescent in the course of the hot dry season [6], whereas the availability of herbage mass is the lowest in winter. Intake of any plants seems to be influenced by their digestibility, physical characteristics, accessibility, and palatability $[7,8]$. The accessibility of any pasture component depends upon 


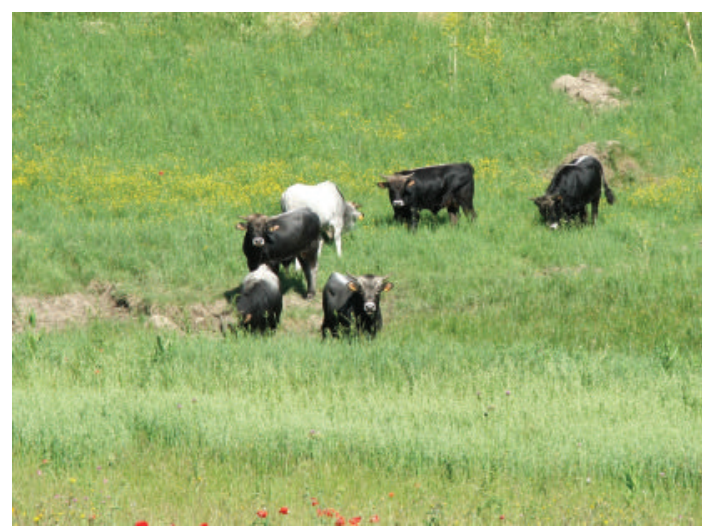

FIGURE 1

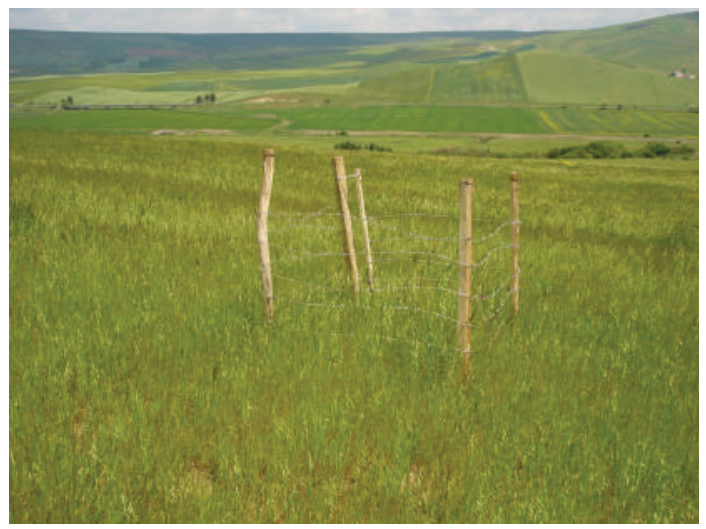

Figure 2

its height, density, and position in the sward relative to other components $[9,10]$. Palatability depends on the interrelationship between a feed's taste and its postingestive feedback, which is determined by an animal's physiological state and food's chemical characteristics [11-13]. Animals discriminate among foods using taste, odour, and sight, which are source of hedonic sensations $[13,14]$. They acquire preferences for nutritious foods and dislike foods with low nutrient content or high toxin levels $[12,13,15]$.

Understanding livestock behaviour, including social relationship, in relation to varying environmental conditions and forage dynamics is fundamental in designing strategies for extensive livestock management.

Therefore, this study aims to describe the behaviour of a semiwild cattle breed kept in a natural environment (as either a small group of young bulls or cows within a family herd) and the interaction of these animals with the environment in terms of ingestion from natural pastures.

\section{Material and Methods}

2.1. Experiment 1. In a study conducted from February to August 2007 in a pasture located in Basilicata (southern Italy) at $338 \mathrm{~m}$ above sea level $\left(40^{\circ} 45^{\prime} 2.16^{\prime \prime} \mathrm{N} ; 16^{\circ} 14^{\prime} 11.76^{\prime \prime} \mathrm{E}\right)$, where the mean annual rainfall is below $600 \mathrm{~mm}$, six Podolian young bulls (Figure 1) were allowed to graze on a

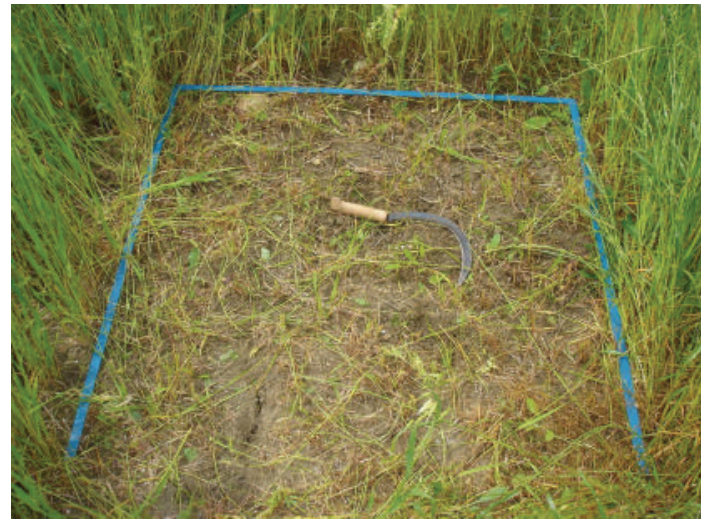

Figure 3

natural fenced pasture of 18 ha of grassland and 2 ha of shrub vegetation. Animals were aged about 11 months at the start of the experiment $(339.83 \pm 10.00 \mathrm{~d})$ and were kept on pasture for the entire finishing period.

Grass availability (DM/ha) was measured monthly using fifteen iron-fenced net boxes $(1.5 \times 1.5 \mathrm{~m}, 1 \mathrm{~m}$ height) (Figure 2), randomly placed on grazing area [16]. Herbage was harvested at ground level from three $1 \times 1 \mathrm{~m}$ areas placed into boxes (Figure 3 ). The total herbage mass was weighted and subsampled to evaluate dry matter and chemical composition and to estimate the botanical composition (grass, legumes, composites, and others).

Two observers carried out both the habituation procedure and the observations. The observers spent several days with the experimental animals in order to accustom the groups to their presence. The success of the habituation was measured in terms of the distance the animals kept from the observers. The habituation procedure ended when the observer was able to move around at a distance of approximately $0.5-1.5 \mathrm{~m}$. Behavioural observations were performed in nine sessions through continuous focal animal recording method (i.e., observing one individual for a specified amount of time and recording all instances of its behaviours) [17]. Observers were balanced across time of the day. Sixhour period of continuous observations was alternatively conducted from $06: 00$ to $12: 00$ and from 12:00 to $18: 00 \mathrm{~h}$. In each session, a different animal was chosen. Therefore, all the animals were included in the observations, whereas three animals were sampled twice.

The duration (accuracy: $1 \mathrm{~s}$ ) of the observed behaviours was recorded. The nine behavioural observations were divided into two seasons: spring (mid-February-mid-June: 5 recordings) and summer (mid-June-August: 4 recordings). The following parameters were recorded: posture (standing or lying) and activity such as grazing (biting or chewing the herbage and walking with muzzle close to the ground), walking, resting (opened or closed eyes, but no other overt activity), ruminating, and alertness, whereas all other behaviours (e.g., drinking, vocalization, self-grooming) were recorded as "other." The proportion of time spent on each behaviour was calculated for each observation session. In addition, behaviours such as self-grooming, licking objects, 
vocalization, and agonistic (pushing, butting, or threatening cospecifics) and nonagonistic interactions (sniffing, horning or nuzzling cospecifics) were recorded as number of events. The distance covered during the observation session was recorded by means of pedometers worn by the observers.

During the 6-hour period, every hour, the number of bites and bite rate (number of bites per grazing minute) were recorded (using a mechanical counter) along with herbage height by means of a herb meter. A bite was defined as the tearing sound that occurred when the forage was severed from the sward. Only prehension bites were counted [18]. Bite mass, chemical composition, and botanical preferences were determined in hand-plucked samples [19] of herbage to simulate the herbage grazed by the animals ( 15 simulated plucks/h). This procedure also allowed estimating the intake rate (bite mass $\times$ bite rate).

Data were analyzed with SAS software [20]. Behavioural data were analyzed using the observation session as the experimental unit. Data on ingestion were analysed using the animal as experimental unit. Both data were subjected to ANOVA with season (spring and summer) as factor. Chemical and botanical compositions of pasture and hand-plucked samples were analyzed using ANOVA with season, source (pasture and hand plucking), and their interactions as factors and the animal as the experimental unit.

2.2. Experiment 2. The experiment was conducted from August to October 2009 in an area located in Basilicata (southern Italy), at an average altitude of $1150 \mathrm{~m}$ above sea level $\left(40^{\circ} 9^{\prime} 52.92^{\prime \prime} \mathrm{N}, 15^{\circ} 59^{\prime} 33.72^{\prime \prime} \mathrm{E}\right)$, where the herd is moved according to the seasonal transhumant routine (consisting of a seasonal displacement of the herd, upland in summer and lowland in winter, in order to find more abundant high-quality grass) and kept from June to November. The pasture was a Mediterranean maquis [21] of 500 ha separated in 25 fenced areas with a prevalence of Graminaceae (Arrhenatherum elatius L., Dactylis glomerata L., Festuca arundinacea, Phleum pratense, Lolium spp.), Leguminosae (Lotus corniculatus, Trifolium spp.), Asteraceae (Achillea millefolium, Carduus spp.), Hypolepidaceae (Pteridium spp.), Rosaceae (Potentilla, Rosa Canina), and Fagaceae (Fagus spp., Quercus spp.). At ten-day intervals animals were moved to a different fenced area.

Grazing behaviour was monitored on 28 Podolian (14 suckling and 14 nonsuckling) cows (from 4 to 12 years of age). They were part of a herd including a total number of 240 animals from three different breeds (Podolian, Chianina, and Romagnola). These animals grazed from 6.00 to 20.00 and were recovered in a fenced yard during the night. Suckling cows were always with their calves aged 4-5 months (Figure 4).

Behavioural observations were performed in ten sessions through continuous focal animal recording method [17] by two observers. Nine-hour period of continuous observations was conducted from 07:00 to 19:00.

The duration (accuracy: 1s) of the observed behaviours was recorded. Behavioural categories were the same as described for Podolian young bulls with the addition of maternal care. The proportion of time spent on each

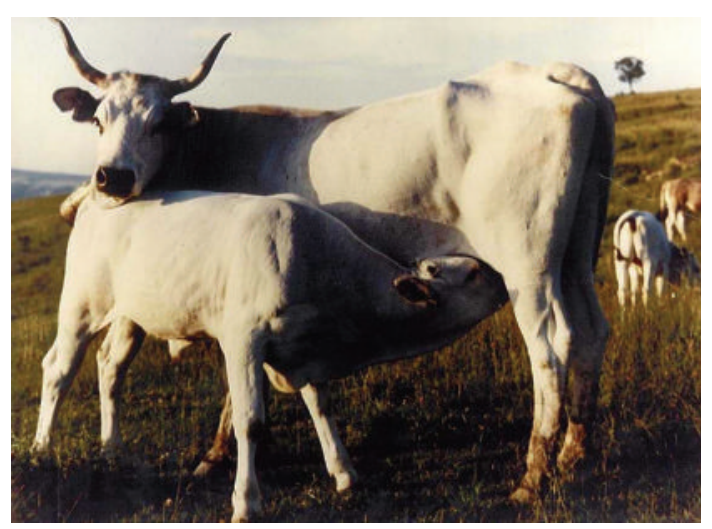

FIGURE 4

behaviour was calculated for each observation session. The variables recorded as number of events were as described for young bulls, with the addition of suckling and calf grooming. The distance covered during the observation session was recorded by means of pedometer.

During the 9-h period, 1 minute every hour, bite rate (number of bites per grazing minute) was continuously recorded using a mechanical counter. Bite mass and botanical preferences were determined in hand-plucked samples [19] of herbage to simulate the herbage grazed by the animals (15 simulated plucks/h). This procedure allowed to estimate intake rate (bite mass $\times$ bite rate). Botanical and chemical compositions of hand-plucked samples were determined as previously described for Podolian young bulls.

Behavioural data related to time budget and number of events were analyzed using the observation session as the experimental unit. These data were subjected to ANOVA with the presence of calf and season (summer and autumn) and their interaction as factors. Data concerning suckling and calf grooming were subjected to the analysis of variance with season as factor.

\section{Results and Discussion}

\subsection{Experiment 1}

3.1.1. Time Budget and Social Behaviour. The distance covered by Podolian young bulls in two seasons is reported in Table 1. It was similar to that observed by Krohn et al. [22] in dairy cows kept in extensive environment $(1.7 \mathrm{~km})$, but higher than that covered by dairy cows $(0.6 \mathrm{~km})$ kept in loose housing systems [23]. In addition, the mean distance travelled was, albeit not significantly, lower in summer as compared with spring. Accordingly, in response to high ambient temperature $\left(34\right.$ versus $\left.15^{\circ} \mathrm{C}\right)$, walking $(P<.001)$ and standing $(P<.05)$ were lower in summer, whereas inactivity was higher $(P<.05)$. Dumont et al. [24] observed that daily distance walked by cattle either increased or remained relatively constant over the grazing season for animals at a low stocking rate, which suggests that they keep on exploring the grazing area. Other authors report that extensively grazed cattle [25] maintain their selective effort late in the season 
TABLE 1: Activity budget (means \pm SE) of Podolian young bulls expressed by season.

\begin{tabular}{lccc}
\hline & Spring & Summer & $P$ \\
\hline Distance travelled, km & $1.33 \pm 0.33$ & $2.00 \pm 0.57$ & .423 \\
Standing $^{1}$ & $67.75 \pm 4.55$ & $43.26 \pm 5.10$ & .009 \\
Grazing $^{1}$ & $43.60 \pm .885$ & $28.72 \pm 5.45$ & .081 \\
Walking $^{1}$ & $8.42 \pm 1.11$ & $0.94 \pm 1.24$ & .003 \\
Inactivity $^{1}$ & $23.19 \pm 3.62$ & $39.26 \pm 4.05$ & .021 \\
Alertness $^{1}$ & $6.92 \pm 1.95$ & $1.33 \pm 2.08$ & .085 \\
Ruminating $^{1}$ & $14.87 \pm 2.66$ & $29.03 \pm 2.97$ & .009 \\
Other $^{1}$ & $2.99 \pm 1.50$ & $0.71 \pm 1.68$ & .346 \\
\hline
\end{tabular}

${ }^{1}$ Data expressed as percentage of time.

TABle 2: Other activities (means $\pm \mathrm{SE}$ ) of Podolian young bulls expressed by season.

\begin{tabular}{lccc}
\hline & Spring & Summer & $P$ \\
\hline Self grooming $^{1}$ & $13.20 \pm 3.12$ & $4.00 \pm 3.49$ & .090 \\
Allogrooming $^{1}$ & $4.00 \pm 1.75$ & $3.50 \pm 1.95$ & .854 \\
Agonistic interactions $^{1}$ & $3.00 \pm 1.53$ & $3.00 \pm 1.71$ & 1.000 \\
Nonagonistic interactions $^{1}$ & $10.40 \pm 2.43$ & $9.50 \pm 2.71$ & .812 \\
Object licking $^{1}$ & $4.20 \pm 1.03$ & $0.75 \pm 1.16$ & .062 \\
Vocalisations $^{1}$ & $6.80 \pm 1.71$ & $0.01 \pm 1.92$ & .033 \\
\hline
\end{tabular}

${ }^{1}$ Data expressed as number of events.

when the proportion of reproductive and senescent material in the sward had increased. However, these results are not necessarily in contrast, as the supplementation ( 2 to $4 \mathrm{~kg}$ of oat, barley, and field bean flour) given to the grazing animals in this study can have reduced the motivation to explore and ingest material of poor quality from pasture. In general, cattle allowed to graze are perceived as animals with higher welfare standards because they can express natural behaviours, such as grazing and exploration [26]. Alertness tended to be higher in spring than in summer $(P<.10)$, as a possible consequence of the higher foraging activity, during which animals are more vulnerable to attacks from potential predators [27].

Podolian young bulls showed low agonistic (Figure 5) and nonagonistic interactions (Table 2), as possible consequences of reduced competition for resources (food, water, resting areas, etc.) and increased attention to the environment [28]. A lower number of nonagonistic social interactions, such as sniffing and rubbing, have been also observed by Krohn [29] in extensively kept dairy cows as compared with animals in intensive systems. Competition for resources as well as inadequate housing design is an important causal factor that may induce and increase social tension and agonistic behaviours [30]. Our results are in agreement with those obtained in early studies on cattle behaviour [29,31]. According to Bouissou and Boissy [32], adult cattle show less agonistic interactions when they are on pasture. The mean number of agonistic events recorded in this study is much lower than that reported in previous experiments [31,33], possibly because the bulls were all part of one herd since their birth, consequently their social status was well established,

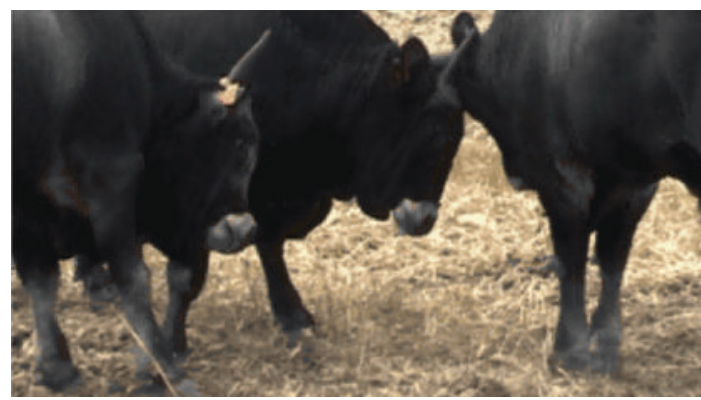

Figure 5

whereas agonistic interactions prominently occur in occasion of establishing the social order in dynamic groups [30]. Selfgrooming was higher in spring than in summer $(P<.01)$. This comfort behaviour is closely related to hygiene and possibly associated to the higher rain falls and body dirtiness usually observed in this season. Vocalizations were higher in spring $(P<.05)$. Vocal signals are used to keep contact with and locate other herd members; therefore, they were more frequently expressed in spring when animals moved more often for forage search and ingestion [34].

3.1.2. Ingestive Behaviour. In Mediterranean environments, biomass availability is much lower in summer than in spring $[5,28]$, although, in this study, differences were not significant due to the high variability of samples. As to botanical composition, season significantly affected percent grasses, which were lower in summer $(P<.01)$, and composites $(P<$ $.05)$, which increased in summer. In agreement with Hessle et al. [35], in both pasture and hand-plucked samples, chemical composition was affected by season. In particular, dry matter $(P<.001)$, crude fibre $(P<.01)$, and NDF $(P<.05)$ increased during summer as compared with spring, whereas crude protein $(\mathrm{CP} ; P<.05)$ and ash $(P<.05)$ percentages and meat feed units (MFU: net energy content of one $\mathrm{kg}$ of standard barley for meat production, corresponding to $1820 \mathrm{kcal})$ decreased $(P<.01)$.

The botanical composition of pasture and hand-plucked samples was similar (Table 3 ). However, the diet selected by the animals, as assessed by hand plucking, was higher in $\mathrm{CP}$ percentages in comparison with pasture samples (12.17 \pm $0.87 \%$ versus $7.11 \pm 0.93 \%$, resp.; $P<.01)$ and tended to have higher MFU values $(0.63 \pm 0.02 \mathrm{MFU} / \mathrm{kg} \mathrm{DM}$ versus $0.58 \pm 0.02 \mathrm{MFU} / \mathrm{kg} \mathrm{DM} ; P<.10)$. This may be ascribed to the "foraging strategy" of the animal [19]. According to this theory, grazing herbivores make a series of short-term decisions (e.g., about which plants or plant portions to select and how long to search) in order to ingest a diet adequate to satisfy their nutrient requirements for maintenance, growth and reproduction $[4,24]$.

The ingestive behaviour variables of Podolian young bulls are reported in Table 4 . While foraging, an animal takes a series of bites varying in size from the herbage on offer. Combination of bite size and short-term rate of biting is defined as the short-term intake rate. These variables are related, as larger bite sizes need more time for processing 
TABLe 3: Botanical and chemical composition of pasture and Podolian bulls' diet as observed in hand-plucked samples.

\begin{tabular}{|c|c|c|c|c|c|}
\hline & \multicolumn{2}{|c|}{ Pasture } & \multicolumn{2}{|c|}{ Hand-plucked samples } & \multirow{2}{*}{ SEM } \\
\hline & Spring & Summer & Spring & Summer & \\
\hline Herbage mass, $\mathrm{g} / \mathrm{m}^{2}$ & 849.72 & 568.03 & - & - & 399.74 \\
\hline Grass, \% & 81.83 & 60.63 & 78.62 & 61.26 & 5.87 \\
\hline Legumes, \% & 5.99 & 6.36 & 4.62 & 3.27 & 2.12 \\
\hline Composites, \% & 7.24 & 23.15 & 2.98 & 21.32 & 6.14 \\
\hline Others, \% & 4.94 & 9.86 & 13.78 & 14.15 & 3.03 \\
\hline Dry matter & 29.98 & 66.72 & 26.97 & 61.82 & 6.12 \\
\hline Crude protein, \% DM & 9.06 & 5.18 & 13.40 & 10.96 & 1.31 \\
\hline Ether extract, \% DM & 1.34 & 1.20 & 1.35 & 1.58 & 0.17 \\
\hline Crude fiber, \% DM & 24.34 & 33.95 & 21.04 & 30.58 & 2.24 \\
\hline Ash, \% DM & 13.29 & 9.98 & 16.78 & 8.06 & 2.53 \\
\hline $\mathrm{NDF}^{1}, \% \mathrm{DM}$ & 47.09 & 59.47 & 45.35 & 56.10 & 4.07 \\
\hline $\mathrm{MFU}^{2}, \mathrm{~kg} \mathrm{DM}$ & 0.64 & 0.51 & 0.68 & 0.57 & 0.03 \\
\hline
\end{tabular}

${ }^{1}$ Neutral detergent fiber.

${ }^{2}$ Meat feed unit (INRA,1988).

TABLE 4: Ingestive behaviour (means \pm SE) of Podolian young bulls.

\begin{tabular}{lccc}
\hline & Spring & Summer & $P<$ \\
\hline Bite rate, $\mathrm{n} / \mathrm{min}$ & $45.79 \pm 2.99$ & $26.75 \pm 5.17$ & .01 \\
Bite mass, g DM & $1.12 \pm 0.15$ & $1.19 \pm 0.11$ & $\mathrm{NS}$ \\
Intake rate, g DM /min & $54.88 \pm 4.89$ & $32.02 \pm 8.48$ & .05 \\
Sward height, cm & $29.12 \pm 4.29$ & $42.87 \pm 7.43$ & .10 \\
\hline
\end{tabular}

and swallowing. Usually ruminants prefer plants with faster ingestion [8]. In this experiment, bite rate resulted in being higher $(P<.01)$ in spring than in summer. Similarly, Lamoot et al. [36] reported that bite rate of cattle was the highest in spring than in the other seasons, probably because, in this period plant growth starts and provides the herbivores with high quality forage. In our study, crude fibre and NDF percentages were lower in spring. Therefore, seasonal changes in forage quality parameters were reflected in adaptations of ingestive behaviour. No significant differences between the seasons were observed for bite mass. Therefore, as a consequence of a higher bite rate during spring, intake rate was higher in spring than in summer $(P<$ $.05)$. Cattle usually exhibit very typical selectivity patterns preferentially selecting against reproductive grass patches $[24,37]$, especially as these become more mature [38].

Herbage tended to be higher in summer $(P<.10)$. In agreement with Gibb et al. [39] and Burns and Sollenberger [40], this variable was negatively correlated with bite rate $(r=-0.60 ; P<.001)$ and positively related to bite mass $(r=0.55 ; P<.01)$. In particular, in an experiment by Boval et al. [41], bite mass increased by $9 \mathrm{mg}$ per additional $\mathrm{cm}$ of extended tiller length. A lower biting rate would be a consequence of greater harvested leaf length or a higher bite mass requiring more time for prehension, manipulation, and mastication [42].

Although it is often suggested that bovids are morphologically constrained to graze on very short swards because of the lack of the upper incisors [43], studies of patch

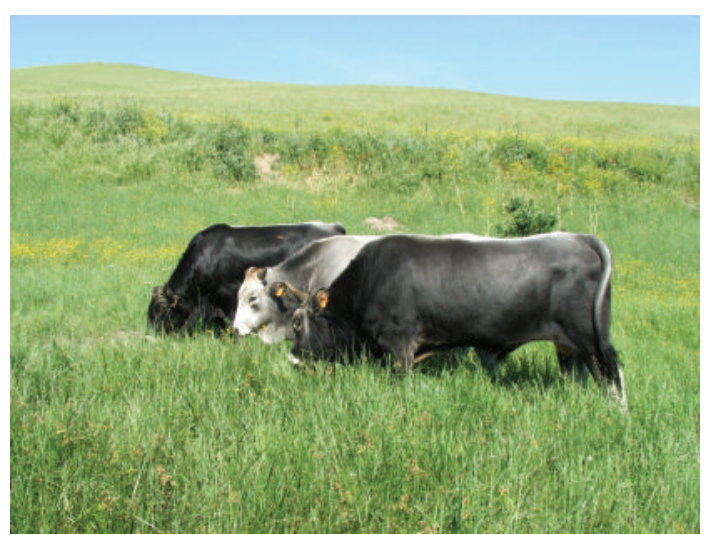

Figure 6

selection by cattle within grassland reported that cattle prefer vegetative patches of medium height (Figure 6) even if they could have achieved greater intakes on taller mature patches $[37,38]$. Accordingly, as already reported, Podolian young bulls showed higher intake rates in spring than in summer.

\subsection{Experiment 2}

3.2.1. Time Budget and Social Behaviour. No significant differences between seasons were observed (Tables 5 and 6). Similarly to other studies $[35,44]$, Podolian cows spent most of their time on grazing activity, followed by walking, whereas less time was spent resting (Table 5).

Grazing occupies a large amount of time in both dairy cows (about 8 hours/day) and beef cattle (about 9 hours/day) [45]. The total duration of grazing per $24 \mathrm{~h}$ ranges from 4 to $12 \mathrm{~h}$ depending on the quality and variety of the vegetation, the climate, and the competition to access grazing zones [46-50]. In the present study, Podolian cows always showed grazing times higher than $50 \%$, that on $24 \mathrm{~h}$ basis would be higher than $12 \mathrm{~h}$. However, our results are not necessarily 
TABle 5: Activity budget expressed by Podolian cows in two seasons (means $\pm \mathrm{SE}$ ).

\begin{tabular}{lccc}
\hline & Summer & Autumn & $P$ \\
\hline Distance travelled, km & $1.24 \pm 0.23$ & $0.89 \pm 0.23$ & .305 \\
Standing $^{1}$ & $95.84 \pm 1.66$ & $96.07 \pm 1.66$ & .924 \\
Grazing $^{1}$ & $52.45 \pm 7.04$ & $60.57 \pm 7.04$ & .429 \\
Walking $^{1}$ & $12.86 \pm 3.03$ & $12.56 \pm 3.03$ & .945 \\
Inactivity $^{1}$ & $9.16 \pm 2.91$ & $7.07 \pm 2.91$ & .620 \\
Alertness $^{1}$ & $0.76 \pm 0.38$ & $0.14 \pm 0.38$ & .268 \\
Ruminating lying $_{\text {Ruminating standing }}$ & $5.25 \pm 2.86$ & $6.63 \pm 2.86$ & .739 \\
Maternal care $^{1}$ & $2.65 \pm 1.32 \pm 3.90$ & $5.20 \pm 3.90$ & .092 \\
Other $^{1}$ & $0.35 \pm 0.29$ & $1.19 \pm 1.32$ & .464 \\
\hline
\end{tabular}

${ }^{1}$ Data expressed as percentage of time.

TABle 6: Other activities ${ }^{1}$ expressed by Podolian cows in two seasons (means $\pm \mathrm{SE}$ ).

\begin{tabular}{lccc}
\hline & Summer & Autumn & $P$ \\
\hline Self-grooming & $4.00 \pm 1.65$ & $2.75 \pm 1.65$ & .141 \\
Allogrooming & $0.75 \pm 0.29$ & $0.37 \pm 0.29$ & .375 \\
Calf grooming & $0.75 \pm 0.56$ & $1.25 \pm 0.56$ & .550 \\
Suckling & $0.50 \pm 0.20$ & $0.01 \pm 0.20$ & .134 \\
Agonistic interactions & $0.25 \pm 0.14$ & $0.12 \pm 0.14$ & .553 \\
Drinking & $0.50 \pm 0.18$ & $0.37 \pm 0.18$ & .642 \\
Vocalisations & $1.25 \pm 0.48$ & $0.37 \pm 0.48$ & .215 \\
\hline
\end{tabular}

${ }^{1}$ Data expressed as no. of events.

TABLe 7: Botanical and chemical composition of Podolian cows' diet as observed in hand-plucked samples (means $\pm \mathrm{SE}$ ).

\begin{tabular}{lc}
\hline Grass, \% & $68.38 \pm 2.84$ \\
Legumes, \% & $0.80 \pm 0.34$ \\
Composites, \% & $1.45 \pm 1.16$ \\
Ferns, \% & $15.69 \pm 1.89$ \\
Other plants, \% & $13.63 \pm 2.72$ \\
Dry matter & $45.08 \pm 2.26$ \\
Crude protein, \% DM & $9.99 \pm 0.62$ \\
Ether extract, \% DM & $1.44 \pm 0.07$ \\
Crude fiber, \% DM & $29.66 \pm 0.87$ \\
Ash, \% DM & $7.66 \pm 0.55$ \\
$\mathrm{NDF}^{1}, \% \mathrm{DM}$ & $60.32 \pm 1.39$ \\
$\mathrm{MFU}^{2} / \mathrm{kg} \mathrm{DM}$ & $0.68 \pm 0.01$ \\
\hline
\end{tabular}

${ }^{1}$ Neutral detergent fibre.

${ }^{2}$ Meat feed unit.

in contrast with those previously reported, as we conducted the observations during day time, when grazing activity is predominantly performed. Total daily grazing time tends to be relatively stable in order to meet animals' nutritional requirements at the circadian level [51]. Following ingestion comes rumination, which allows cattle to regurgitate, masticate, and then swallow food that they have previously ingested into the rumen. In general, standing was the posture prevailing in the three breeds with levels even higher than

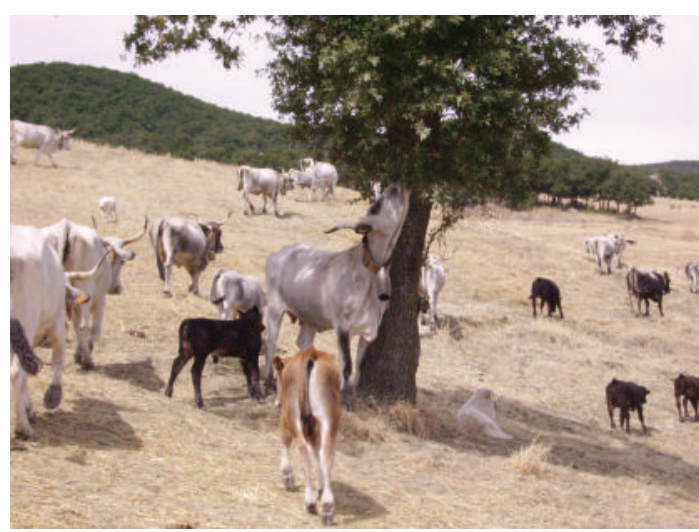

FIGURE 7

those previously reported (73.01\%) [52]. Again, this result may be attributed to the fact that observations were not conducted during night time, when resting and lying are more often performed.

As also observed in young bulls, low levels of social interactions (agonistic interactions, allogrooming, and calf grooming) were expressed by animals permanently kept on pasture (Table 6).

3.2.2. Ingestive Behaviour. Cattle and sheep usually exhibit typical selectivity patterns preferentially selecting bites containing legumes and forbs [53, 54]. Compared to grasses, legumes such as white clover are often associated with higher level of intake [55]. Penning et al. [56], Baumont [57], and Assoumaya et al. [58] suggested that forage legumes are more quickly reduced in small particles than grasses and that less time is needed to take and masticate a similar bite for clover than for grass. However, pastures in marginal areas of southern Italy are characterized by a prevalence of grasses over legumes [28], and in this study hand-plucked samples reflected the same predominance (Table 7 ). In addition, at the end of summer and in autumn (i.e., when the experiment was conducted) grasses with erect stalks tend to cover the underlying legumes, which become less accessible to grazing animals.

In Table 7 the main features of the diet ingested by Podolian cows, as assessed by hand plucking, are reported. Podolian cows chose a high percentage of ferns, which may be toxic (e.g., Pteridium aquilinum). The prevalence of ferns in Podolian hand-plucked samples may be due to the ability of this breed to detoxify toxins of plants that appear to be more often ingested by native animals that coevolved with the vegetation than in selected breeds [59]. Tree foliage was another abundant part of Podolian cow diet, as the category "other plants" predominantly included woody plants (Figure 7), such as Fagus sylvatica.

Cattle feeding decisions are at least partly dictated by their will to maximize their energy balance, but, as vegetation quality is extremely variable, animals need to select specific nutrients in order to ingest a diet adequate to satisfy their nutrient requirements for maintenance, growth, and reproduction $[19,24]$. In this study, Podolian cows were able 
to perform an efficient nutrient selection with $9.99 \pm 0.62 \%$ $\mathrm{CP}$ and $0.68 \pm 0.01 \mathrm{MFU} / \mathrm{kg} \mathrm{DM}$ with an ingestive behaviour characterised by a bite rate $(\mathrm{n} / \mathrm{min})$, a bite mass (g DM) and an intake rate $(\mathrm{g} \mathrm{DM} / \mathrm{min})$ of $36.63 \pm 1.99,2.29 \pm 0.15$, and $84.02 \pm 7.32$, respectively.

The activity budget of free-ranging animals was characterized by high locomotor and feeding activities. They exhibited a high degree of adaptability to the local phytocoenosis with high levels of ferns' and tree foliage intakes performed by cows and the selection of a diet more nutritious than pasture performed by young bulls. These results along with the low levels of agonistic interactions recorded in the two experiments suggest that extensive systems based on grazing provide a natural environment for the expression of cattle species-specific behaviour.

\section{References}

[1] F. Napolitano, C. Pacelli, G. De Rosa, A. Braghieri, and A. Girolami, "Sustainability and welfare of Podolian cattle," Livestock Production Science, vol. 92, no. 3, pp. 323-331, 2005.

[2] L. Hernandez, H. Barral, G. Halffter, and S. S. Colon, "A note on the behavior of feral cattle in the Chihuahuan Desert of Mexico," Applied Animal Behaviour Science, vol. 63, no. 4, pp. 259-267, 1999.

[3] F. Napolitano, G. Caporale, A. Carlucci, and E. Monteleone, "Effect of information about animal welfare and product nutritional properties on acceptability of meat from Podolian cattle," Food Quality and Preference, vol. 18, no. 2, pp. 305-312, 2007.

[4] I. J. Gordon, "Animal-based techniques for grazing ecology research," Small Ruminant Research, vol. 16, no. 3, pp. $203-$ 214, 1995.

[5] P. Martiniello and N. Berardo, "Residual fertilizer effects on dry-matter yield and nutritive value of Mediterranean pastures," Grass and Forage Science, vol. 62, no. 1, pp. 87-99, 2007.

[6] P. Martiniello, G. M. Terzano, C. Pacelli, M. Mazzi, and E. Sabia, "Qualitative and quantitative biomass production of improved Mediterranean pasture on phytocoenoses and body growing in young buffalo heifers until puberty," Italian Journal of Animal Science, vol. 6, pp. 1241-1244, 2007.

[7] P. A. Kenney and J. L. Black, "Factors affecting diet selection by sheep. I. Potential intake rate and acceptability of feed," Australian Journal of Agricultural Research, vol. 35, pp. 551$563,1984$.

[8] G. De Rosa, V. Fedele, F. Napolitano, L. Gubitosi, A. Bordi, and R. Rubino, "Dietary preferences in adult and juvenile goats," Animal Science, vol. 65, no. 3, pp. 457-463, 1997.

[9] J. Hodgson, "Ingestive behaviour," in Herbage Intake Handbook, J. D. Leaver, Ed., pp. 113-138, British Grassland Society, Hurley, UK, 1982.

[10] J. A. Milne, "Diet selection by grazing animals," Proceedings of the Nutrition Society, vol. 50, no. 1, pp. 77-85, 1991.

[11] G. De Rosa, F. Napolitano, V. Marino, and A. Bordi, "Induction of conditioned taste aversion in goats," Small Ruminant Research, vol. 16, no. 1, pp. 7-11, 1995.

[12] F. D. Provenza, "Postingestive feedback as an elementary determinant of food preference and intake in ruminants," Journal of Range Management, vol. 48, no. 1, pp. 2-17, 1995.
[13] F. D. Provenza, "Acquired aversions as the basis for varied diets of ruminants foraging on rangelands," Journal of Animal Science, vol. 74, no. 8, pp. 2010-2020, 1996.

[14] G. De Rosa, L. Moio, F. Napolitano, F. Grasso, L. Gubitosi, and A. Bordi, "Influence of flavor on goat feeding preferences," Journal of Chemical Ecology, vol. 28, no. 2, pp. 269-281, 2002.

[15] I. Kyriazakis, T. G. Papachristou, A. J. Duncan, and I. J. Gordon, "Mild conditioned food aversions developed by sheep towards flavors associated with plant secondary compounds," Journal of Chemical Ecology, vol. 23, no. 3, pp. 727-746, 1997.

[16] J. A. C. Meijs, R. J. K. Walters, and A. Keen, "Sward methods," in Herbage Intake Handbook, J. D. Leaver, Ed., pp. 11-36, British Grassland Society, Berkshire, UK, 1982.

[17] P. Martin and P. Bateson, Measuring Behaviour, Cambridge University Press, Cambridge, UK, 2007.

[18] L. L. Erlinger, D. R. Tolleson, and C. J. Brown, "Comparison of bite size, biting rate and grazing time of beef heifers from herds distinguished by mature size and rate of maturity," Journal of Animal Science, vol. 68, no. 11, pp. 3578-3587, 1990.

[19] L. J. Gordon and A. W. Illius, "Foraging strategy: from monoculture to mosaic," in Progress in Sheep and Goat Research, A. W. Speedy, Ed., p. 153, CAB International, Wallingford, UK, 1992.

[20] SAS, SAS/STAT User's Guide, Version 6, SAS Institute, Cary, NC, USA, 4th edition, 1990.

[21] J. Rogosic, J. A. Pfister, F. D. Provenza, and D. Grbesa, "Preference and nutritive values of Mediterranean maquis shrubs by sheep and goats," Small Ruminant Research, vol. 64, no. 1-2, pp. 169-179, 2006.

[22] C. C. Krohn, L. Munksgaard, and B. Jonasen, "Behaviour of dairy cows kept in extensive (loose housing/pasture) or intensive (tie stall) environments, I. Experimental procedure, facilities, time budgets-diurnal and seasonal conditions," Applied Animal Behaviour Science, vol. 34, no. 1-2, pp. 37-47, 1992.

[23] K. Kempkens and J. Boxberger, "Locomotion of cattle in loose housing system," in Latest Development in Livestock Housing, vol. 6-87, p. 179, American Society of Agricultural Engineers, St. Joseph, Mich, USA, 1987.

[24] B. Dumont, J. P. Garel, C. Ginane et al., "Effect of cattle grazing a species-rich mountain pasture under different stocking rates on the dynamics of diet selection and sward structure," Animal, vol. 1, no. 7, pp. 1042-1052, 2007.

[25] F. Kohler, F. Gillet, S. Reust et al., "Spatial and seasonal patterns of cattle habitat use in a mountain wooded pasture," Landscape Ecology, vol. 21, no. 2, pp. 281-295, 2006.

[26] P. H. H. Hemsworth, J. L. Barnett, L. Beveridge, and L. R. Matthews, "The welfare of extensively managed dairy cattle: a review," Applied Animal Behaviour Science, vol. 42, no. 3, pp. 161-182, 1995.

[27] M. Mendl and S. Held, "Living in groups: an evolutionary perspective," in Social Behaviour of Farm Animals, L. J. Keeling and H. W. Gonyou, Eds., pp. 7-36, CABI, Wallingford, UK, 2001.

[28] A. Braghieri, C. Pacelli, G. De Rosa, A. Girolami, P. De Palo, and F. Napolitano, "Podolian beef production on pasture and in confinement," Animal, vol. 5, pp. 927-937, 2011.

[29] C. C. Krohn, "Behaviour of dairy cows kept in extensive (loose housing/pasture) or intensive (tie stall) environments. III. Grooming, exploration and abnormal behaviour," Applied Animal Behaviour Science, vol. 42, no. 2, pp. 73-86, 1994.

[30] M. F. Bouissou, A. Boissy, P. Le Neindre, and I. Veissier, "The social behaviour of cattle," in Social Behaviour in Farm 
Animals, L. J. Keeling and H. W. Gonyou, Eds., p. 113, CABI, Wallingford, UK, 2001.

[31] H. K. Wierenga, "The social behaviour of dairy cows: some differences between pasture and cubicle system," in Proceedings of the International Congress on Applied Ethology in Farm Animals, J. Unshelm, G. Van Putten, and K. Zeeb, Eds., p. 135, KTBL, Kiel, Germany, 1984.

[32] M. F. Bouissou and A. Boissy, "The social behaviour of cattle and its consequences on breeding," Productions Animales, vol. 18, no. 2, pp. 87-99, 2005.

[33] K. Miller and D. G. M. Wood-Gush, "Some effects of housing on the social behaviour of dairy cows," Animal Production, vol. 53, pp. 271-278, 1991.

[34] J. M. Watts and J. M. Stookey, "Vocal behaviour in cattle: the animal's commentary on its biological processes and welfare," Applied Animal Behaviour Science, vol. 67, no. 1-2, pp. 15-33, 2000.

[35] A. Hessle, M. Rutter, and K. Wallin, "Effect of breed, season and pasture moisture gradient on foraging behaviour in cattle on semi-natural grasslands," Applied Animal Behaviour Science, vol. 111, no. 1-2, pp. 108-119, 2008.

[36] I. Lamoot, C. Meert, and M. Hoffmann, "Habitat use of ponies and cattle foraging together in a coastal dune area," Biological Conservation, vol. 122, no. 4, pp. 523-536, 2005.

[37] M. F. Wallis De Vries and C. Daleboudt, "Foraging strategy of cattle in patchy grassland," Oecologia, vol. 100, no. 1-2, pp. 98106, 1994.

[38] C. Ginane, M. Petit, and P. D’Hour, “How do grazing heifers choose between maturing reproductive and tall or short vegetative swards?" Applied Animal Behaviour Science, vol. 83, no. 1, pp. 15-27, 2003.

[39] M. J. Gibb, C. A. Huckle, R. Nuthall, and A. J. Rook, "Effect of sward surface height on intake and grazing behaviour by lactating Holstein Friesian cows," Grass and Forage Science, vol. 52, supplement 3, pp. 309-321, 1997.

[40] J. C. Burns and L. E. Sollenberger, "Grazing behavior of ruminants and daily performance from warm-season grasses," Crop Science, vol. 42, no. 3, pp. 873-881, 2002.

[41] M. Boval, A. Fanchone, H. Archimède, and M. J. Gibb, "Effect of structure of a tropical pasture on ingestive behaviour, digestibility of diet and daily intake by grazing cattle," Grass and Forage Science, vol. 62, no. 1, pp. 44-54, 2007.

[42] G. P. Cosgrove, "Grazing behaviour and forage intake," in Proceedings of the International Symposium on Animal Production Under Grazing, pp. 59-80, Departmento de Zootechnia, Universite Federal de Vicosa, Vicosa, Brazil, 1997.

[43] A. W. Illius and I. J. Gordon, "The allometry of food intake in grazing ruminants," Journal of Animal Ecology, vol. 56, no. 3, pp. 989-999, 1987.

[44] R. Huber, R. Baumung, M. Wurzinger, D. Semambo, O. Mwai, and C. Winckler, "Grazing, social and comfort behaviour of Ankole and crossbred (Ankole $\times$ Holstein) heifers on pasture in south western Uganda," Applied Animal Behaviour Science, vol. 112, no. 3-4, pp. 223-234, 2008.

[45] R. E. Taylor and T. D. Field, Scientific Farm Animal Production, Prentice Hall, Upper Saddle River, NJ, USA, 1998.

[46] C. J. C. Phillips and J. D. Leaver, "Seasonal and diurnal variation in the grazing behaviour of dairy cows," in Grazing, vol. 19 of BGS Occasional Symposium, pp. 98-104, 1985.

[47] I. L. Bennett and C. R. Holmes, "Formation of a feeding order in a group of cattle and its relationship with grazing behaviour, heat-tolerance and production," Applied Animal Behaviour Science, vol. 17, no. 1-2, pp. 9-18, 1987.
[48] G. Stakelum, P. Lievense, and P. A. Gleeson, "The relationship between the social dominance of cows in a grazing herd and their milk production, herbage intake and grazing behaviour," Irish Journal of Agricultural Research, vol. 26, pp. 231-235, 1987.

[49] R. N. Funston, D. D. Kress, K. M. Havstad, and D. E. Doornbos, "Grazing behavior of rangeland beef cattle differing in biological type," Journal of Animal Science, vol. 69, no. 4, pp. 1435-1442, 1991.

[50] C. T. Dougherty, F. W. Knapp, P. B. Burrus, D. C. Willis, and P. M. Cornelius, "Moderation of grazing behavior of beef cattle by stable flies (Stomoxys calcitrans L.)," Applied Animal Behaviour Science, vol. 40, no. 2, pp. 113-127, 1994.

[51] M. I. Linnane, A. J. Brereton, and P. S. Giller, "Seasonal changes in circadian grazing patterns of Kerry cows (Bos Taurus) in semi-feral conditions in Killarney National Park, Co. Kerry, Ireland," Applied Animal Behaviour Science, vol. 71, no. 4, pp. 277-292, 2001.

[52] D. Gavojdian, L. T. Cziszter, S. Acatincăi, G. Stanciu, I. Tripon, and M. Feiler, "Daily time budget of dairy cows housed in tie stall barns, during total confinement," Lucrări ştiinţifice Zootehnie şi Biotehnologii, vol. 42, pp. 266-270, 2009.

[53] S. M. Rutter, R. J. Orr, N. H. Yarrow, and R. A. Champion, "Dietary preference of dairy cows grazing ryegrass and white clover," Journal of Dairy Science, vol. 87, no. 5, pp. 1317-1324, 2004.

[54] G. Animut, A. L. Goetsch, G. E. Aiken et al., "Grazing behavior and energy expenditure by sheep and goats co-grazing grass/forb pastures at three stocking rates," Small Ruminant Research, vol. 59, no. 2-3, pp. 191-201, 2005.

[55] H. M. N. Ribeiro Filho, R. Delagarde, and J. L. Peyraud, "Inclusion of white clover in strip-grazed perennial ryegrass swards: herbage intake and milk yield of dairy cows at different ages of sward regrowth," Animal Science, vol. 77, no. 3, pp. 499-510, 2003.

[56] P. D. Penning, A. J. Parsons, R. J. Orr, A. Harvey, and R. A. Champion, "Intake and behaviour responses by sheep, in different physiological states, when grazing monocultures of grass or white clover," Applied Animal Behaviour Science, vol. 45, no. 1-2, pp. 63-78, 1995.

[57] R. Baumont, "Palatabilité et comportement alimentaire chez le ruminant," INRA Productions Animales, vol. 9, no. 5, pp. 349$358,1996$.

[58] C. Assoumaya, D. Sauvant, and H. Archimède, "Étude comparative de l'ingestion et de la digestion des fourrages tropicaux et tempérés," INRA Productions Animales, vol. 20, no. 5, pp. 383-392, 2007.

[59] W. A. Laycock, "Co evolution of poisonous plants and large herbivores on rangelands," Journal of Range Management, vol. 31, pp. 335-342, 1978. 

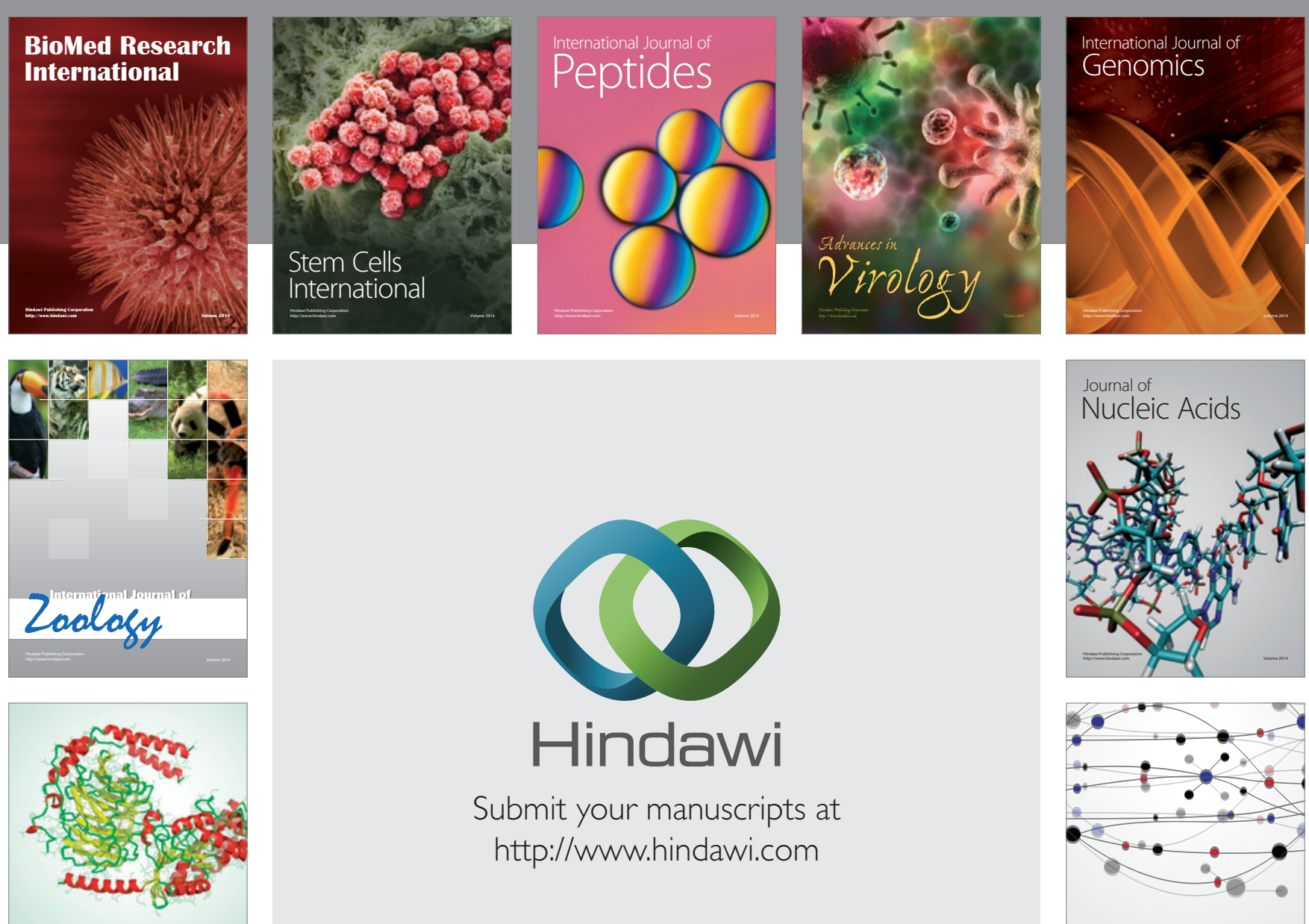

Submit your manuscripts at

http://www.hindawi.com

Signal ${ }^{\text {Jumal }}$ Transduction
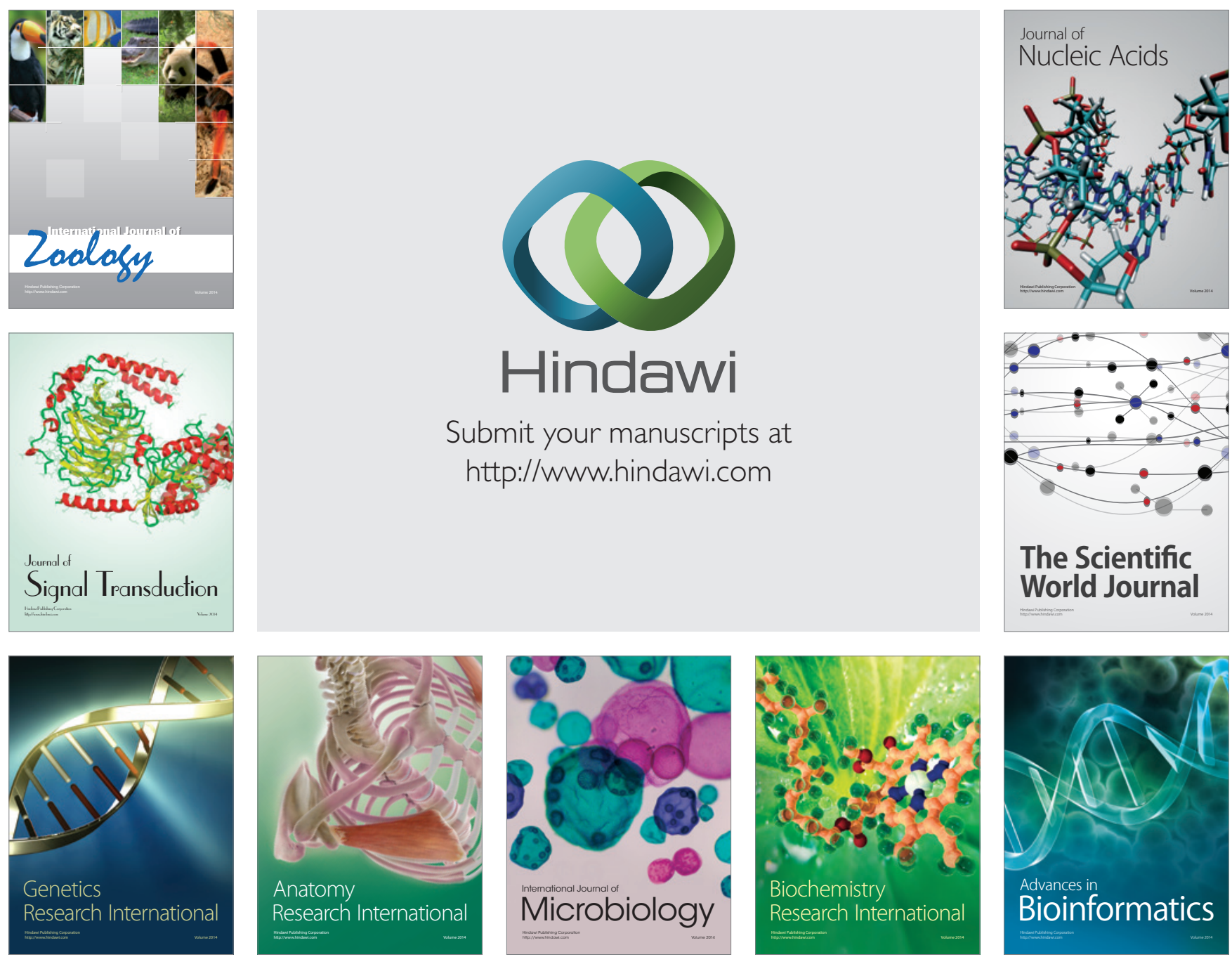

The Scientific World Journal
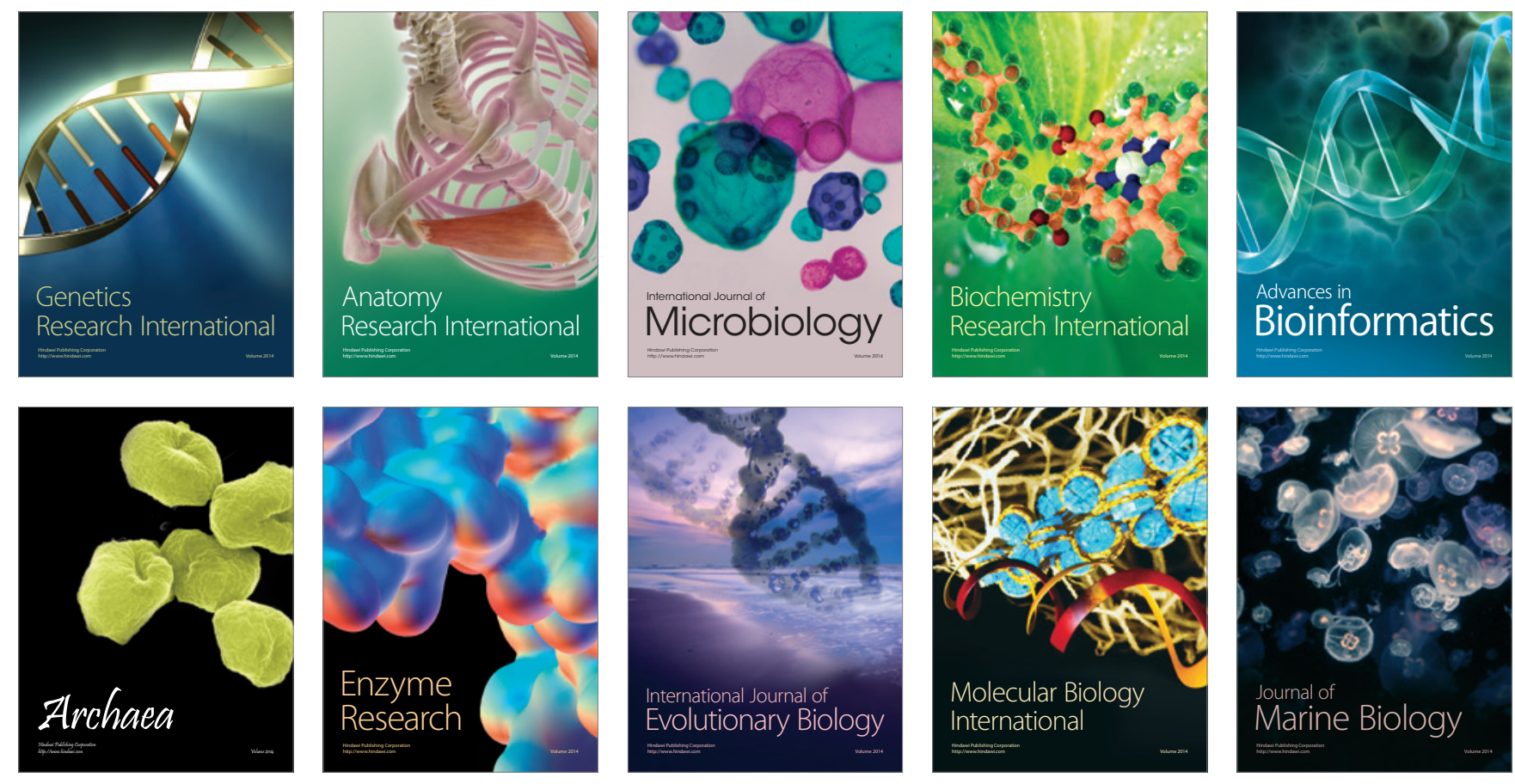